\title{
GATES/GEB as the New Paradigm for Electrolytic Redox Systems
}

\author{
Anna M Michałowska Kaczmarczyk ${ }^{1}$ and Tadeusz Michałowski ${ }^{2 *}$ \\ ${ }^{1}$ Department of Oncology, The University Hospital in Cracow, Poland \\ ${ }^{2}$ Faculty of Engineering and Chemical Technology, Technical University of Cracow, Poland
}

Submission: May 14, 2019; Published: July 10, 2019

*Corresponding author: Tadeusz Michałowski, Faculty of Engineering and Chemical Technology, Technical University of Cracow, 31-155 Cracow, Poland

Keywords: Electrolytic systems; Redox titrations; Balances; GEB; GATES

Abbreviations: GEB: Generalized Electron Balance; GATES: Generalized Approach to Electrolytic Systems; ON: Oxidation Number; EN: Electronegativity; T: Titrant; D: Titrand

\section{Introduction}

One of the most important achievements in formulation of electrolytic systems is the discovery of Generalized Electron Balance (GEB) [1], as an equation (unknown earlier in Science) completing the set of equations needed for thermodynamic solving electrolytic redox systems of any degree of complexity, i.e., equilibrium, metastable and kinetic systems, in monophase, two-phase, multiphase, and multi-solvent media. Redox and non-redox systems are resolved according to Generalized Approach to Electrolytic Systems (GATES) [2,3], formulated by Michałowski; for redox systems, the acronym GATES/GEB is applied.

GATES is referred to aqueous, non-aqueous and mixedsolvent media $A_{s}(s=1, \ldots, s)$, with amphiprotic (co)solvent(s) involved [4]. In aqueous media, the species $X_{i}^{\text {Zi }}$ exist as hydrates $X_{i}^{z_{i}} ; n_{i W} \geq 0$ is a mean number of water $(\mathrm{W}=\mathrm{H} 20)$ molecules attached to $X_{i}^{\mathrm{zi}}$. In the mixed-solvent media, formation of the mixed solvates $X_{i}^{z_{i}} n_{i A 1} \ldots n_{i A s} \ldots n_{i A s}$ is admitted, where $n_{i A s} \geq 0$ is the mean numbers of As molecules attached to $X_{\mathrm{i}}^{\mathrm{Zi}}$ [5].

The GEB is recognized as the law of Nature [1], as the hidden connection of physicochemical laws, and as the breakthrough in thermodynamic theory of electrolytic redox systems. GEB was discovered by Michałowski: as the Approach I to GEB, and as the Approach II to GEB. In the Approach I to GEB, perceived according to 'card game' principle, electron-active elements are perceived as 'players', electron-non-active elements as 'fans', and electrons as 'money'; the knowledge of oxidation numbers is needed here. The Approach II introduces the balance $f_{12}=2 . f_{2}-f_{1}$ as the combination of elemental balances: $f_{1}=f(H)$ for $y_{1}=H$ and $f_{2}=f(O)$ for $y_{2}=O$. Charge balance $\left(f_{0}=C h B\right)$ and other elemental and core balances $f_{k}=f\left(Y_{k}\right)\left(Y_{k} \neq H, O ; k=3, \ldots, k\right)$ are also considered within GATES. A core is considered as a cluster of different atoms with defined composition (expressed by chemical formula), structure and external charge, unchanged in the system in question.

\section{Properties of the balances}

In a non-redox system, the $f_{12}$ is linearly dependent on the balances: $f_{0}, f_{3}, \ldots f_{k}$ i.e., a non-redox system is formulated with use of $K$-1 independent balances $f_{0}, f_{3}, \ldots f_{k}$. In a redox system, $f_{12}$ is linearly independent on the balances $f_{0}, f_{3}, \ldots f_{k^{\prime}}$ i.e., a redox system is formulated with use of $k$ independent balances $f_{0^{\prime}}, f_{12}$, $f_{3}, \ldots f_{k}$. The linear dependency or independency of $f_{12}$ from $f_{0}, f_{3}, \ldots$ $f_{k}$ is then the general property distinguishing between non-redox and redox systems.

Other, general properties are also valid here. Among others, oxidation number $(\mathrm{ON})$ is the derivative concept; application of controversial electronegativity (EN) concept, where an artificial/ doubtful qualification of bonds is made, is thus avoided.

Formulation of GEB according to Approach II needs none prior knowledge of ONs of elements in all components forming a system and in all species present in the system. For a redox system with $K-K^{*}$ 'players', $f_{12}$ is linearly independent on $f_{0}, f_{3}, \ldots$ $f_{k}$, i.e., the redox system is described by $\mathrm{K}$ independent balances $f_{0}, f_{12}, f_{3}, \ldots f_{k}$. For a non-redox system $\left(K^{*}=K\right), f_{12}$ is linearly dependent on $f_{0}, f_{3}, \ldots f_{k}$, i.e., a non-redox system is described 
by $k$-1independent balances $f_{0}, f_{3}, \ldots f_{k^{*}}$ Consequently, the linear combination $f_{12}+f_{0}-\sum_{k=3} k^{*} d_{k} \cdot f_{k} \Leftrightarrow \sum_{k=1}^{k^{*}} d_{k} \cdot f_{k}-f_{0}$ with $d_{k}$ equal to the oxidation numbers of the related elements, is reducible to identity, $0=0$. The linear combination $\sum_{k=1}{ }^{*} d_{k} . f_{k}-f_{0}$ applied to a redox system does not give the identity, also after further combination with $K-K^{*}$ balances for 'players'. The linear combination $\sum_{k=1}{ }^{*} d_{k} \cdot f_{k}-f_{0}$ for a redox system is composed only of components and species, where 'players' are involved. These regularities are valid for electrolytic systems of any degree of complexity, with biological systems included a priori.

\section{Redox titrations}

Static and dynamic systems (aqueous media) were considered within GATES/GEB. Dynamic systems are realizable in simulated titrations, where $\mathrm{V}_{0} \mathrm{~mL}$ of titrant $(\mathrm{T})$ is added into $\mathrm{V}_{0} \mathrm{~mL}$ of titrand (D), at defined point of the titration; $V$ is considered here as the steering variable. In general, $\mathrm{D}$ and $\mathrm{T}$ are composed of one or more solutes dissolved in water. One of solutes in $\mathrm{D}$ is analyte $\mathrm{A}$, one of solutes in $\mathrm{T}$ is reagent $\mathrm{B}$. The results of simulated redox titrations, realized with use of an iterative computer program, e.g. MATLAB [2], are plotted on the graphs: $E=E(\phi)$ and $P H=P H(\phi)$, where $\phi=\frac{c . v}{c \cdot v}$ is the fraction titrated, $c_{0}-$

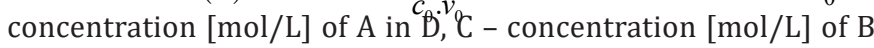
in T. Moreover, concentrations $\left[X^{z i}{ }_{i}\right]$ of the species $X_{i}^{z i} \cdot n_{i w}$ are presented as dynamic speciation curves $\log \left[X_{i}^{z i}\right]=\varphi(\phi)$ ss. The plots related to different redox systems are presented in numerous articles, e.g. in [6-18], and other papers cited therein. Relatively simple redox systems are considered in $[6,7]$.

\section{Final comments}

GATES provides the best thermodynamic tool, the entrance step towards better understanding the physicochemical concepts within biomedical chemistry. The knowledge of chemical processes is the basis for understanding the phenomena occurring in cells and in the body, perceived as the most complex electrolytic systems. This way, the interdisciplinary relationship of chemistry with physics, biology, pharmacy and medicine can (should) be highlighted. The description of the systems according to GATES (and GATES/ GEB in particular) principles is based on algebraic equations, not on the stoichiometry of reactions, practiced hitherto in scientific papers and book literature. The GATES proves to be the most useful on the preliminary stages of research programs. From the authors' viewpoint, stoichiometry is only a kind of 'dummy' [8-19], a relic from the late eighteenth century.

\section{References}

1. Michałowska Kaczmarczyk AM, Spórna Kucab A, Michałowski T (2017) Generalized Electron Balance (GEB) as the Law of Nature in Electrolytic Redox Systems. In: Ali Khalid MA (Eds.), Redox: Principles and Advanced Applications, InTech 2: 9-55.

2. Michałowski T (2011) Application of GATES and MATLAB for Resolution of Equilibrium, Metastable and Non-Equilibrium Electrolytic Systems, In: Michałowski T (Eds.), Applications of MATLAB in Science and Engineering, In Tech - Open Access publisher in the fields of Science, Technology and Medicine, Chapter 1: 1-34.
3. Michałowska Kaczmarczyk AM, Michałowski T (2014) GATES as the Unique Tool for Simulation of Electrolytic Redox and Non-Redox Systems. Journal of Analytical \& Bioanalytical Techniques 5(4): 1-5.

4. Michałowski T, Pilarski B, Asuero AG, Michałowska-Kaczmarczyk AM (2019) Modelling of Acid-Base Proper-ties in Binary-Solvent Systems. In: Wypych G (Eds.), "Handbook of Solvents", (Vol. 1) (3 $3^{\text {rd }}$ Edn), Properties, ChemTec Publishing, Toronto 9.4: 665-690.

5. Michałowska Kaczmarczyk AM, Michałowski T (2014) Generalized Electron Balance for Dynamic Redox Systems in Mixed-Solvent Media. Journal of Analytical Sciences, Methods and Instrumentation 4(4): 102-109.

6. Meija J, Michałowska Kaczmarczyk AM, Michałowski T (2017) Redox titration challenge. Analytical and Bioanalytical Chemistry 409(1): 1113.

7. Michałowski T, Michałowska Kaczmarczyk AM, Meija J (2017) Solution of redox titration challenge. Anal Bioanal Chem 409(17): 4113-4115.

8. Michałowski $\mathrm{T}$ (2010) The Generalized Approach to Electrolytic Systems. I. Physicochemical and Analytical Implications, Critical Reviews in Analytical Chemistry 40(1): 2-16.

9. Michałowski T, Pietrzyk A, Ponikvar Svet M, Rymanowski M (2010) The Generalized Approach to Electrolytic Systems: II. The Generalized Equivalent Mass (GEM) Concept. Critical Reviews in Analytical Chemistry 40(1): 17-29.

10. Michałowski T, Toporek M, Michałowska Kaczmarczyk AM, Asuero AG (2013) New Trends in Studies on Electrolytic Redox Systems. Electrochimica Acta 109: 519-531.

11. Michałowski T, Michałowska Kaczmarczyk AM, Toporek M (2013) Formulation of general criterion distinguishing between non-redox and redox systems. Electrochimica Acta 112: 199-211.

12. Michałowska Kaczmarczyk AM, Toporek M, Michałowski T (2015) Speciation Diagrams in Dynamic Iodide + Dichromate System. Electrochimica Acta 155: 217-227.

13. Toporek M, Michałowska Kaczmarczyk AM, Michałowski T (2015) Symproportionation versus Disproportionation in Bromine Redox Systems. Electrochimica Acta 171: 176-187.

14. Michałowska Kaczmarczyk AM, Asuero AG, Toporek M, Michałowski T (2015) "Why not stoichiometry" versus "Stoichiometry - why not?" Part II. GATES in context with redox systems. Critical Reviews in Analytical Chemistry 45(3): 240-268.

15. Michałowska Kaczmarczyk AM, Michałowski T, Toporek M, Asuero AG (2015) "Why not stoichiometry" versus "Stoichiometry - why not?" Part III, Extension of GATES/GEB on Complex Dynamic Redox Systems. Critical Reviews in Analytical Chemistry 45(4): 348-366.

16. Michałowska Kaczmarczyk AM, Spórna Kucab A, Michałowski T (2017) A Distinguishing Feature of the Balance $2 \cdot f(0)-f(H)$ in Electrolytic Systems. The Reference to Titrimetric Methods of Analysis, In: Vu Dang Hoang (Eds.), Advances in Titration Techniques. InTech Chap 6: 173207.

17. Michałowska Kaczmarczyk AM, Spórna Kucab A, Michałowski T (2017) Solubility products and solubility con-cepts, In: Akitsu T (Eds), Descriptive Inorganic Chemistry. Researches of Metal Compounds. InTech Chap 5: 93-134.

18. Michałowska Kaczmarczyk AM, Spórna Kucab A, Michałowski T (2017) Principles of Titrimetric Analyses According to Generalized Approach to Electrolytic Systems (GATES), In: Vu Dang Hoang (Eds.), Advances in Titration Techniques, InTech Chap 5: 133-171.

19. Michałowska Kaczmarczyk AM, Asuero AG, Michałowski T (2015) "Why not stoichiometry" versus "Stoichiometry - why not?" Part I. General context. Critical Reviews in Analytical Chemistry 45(2): 166188. 
Your next submission with Juniper Publishers will reach you the below assets

- Quality Editorial service

- Swift Peer Review

- Reprints availability

- E-prints Service

- Manuscript Podcast for convenient understanding

- Global attainment for your research

- Manuscript accessibility in different formats

( Pdf, E-pub, Full Text, Audio)

- Unceasing customer service

Track the below URL for one-step submission

https://juniperpublishers.com/online-submission.php 